\title{
Elaboration of an algorithm for wound evaluation and treatment
}

\author{
Elaboração de algoritmo para avaliação e tratamento de ferida
}

Elaboración de algoritmo para evaluación y tratamiento de herida

João Batista da Cunhaํ, Rosimar Aparecida Alves Dutra², Geraldo Magela Salomé1

ORCID IDS

Cunha JB (iD http://orcid.org/0000-0001-7614-4885

Dutra RAA (D) http://orcid.org/0000-0001-9080-4800

Salomé GM (D) http://orcid.org/0000-0002-7315-4866
HOW TO CITE

Cunha JB; Dutra RAA; Salomé GM. Elaboration of an algorithm for wound evaluation and treatment. ESTIMA, Braz. J. Enterostomal Ther., 16:e2018. doi: 10.30886/estima.v16524

\begin{abstract}
Objectives: To develop an algorithm for evaluation and treatment of wounds and to test their internal reliability. Method: Crosssectional and descriptive study. For the construction of the algorithm, a review of the literature was realized with databases of health sciences and consultation of books and theses of this area published in the last 10 years, using as descriptors: acute and chronic wounds; wound evaluation; evaluation tools; dressings; nursing evaluation; wound healing and nursing care; and algorithms. Two hundred nurses with at least 12 months of experience in wound care were contacted and 38 of them completed the evaluation questionnaire. The internal consistency of the algorithm was measured by Cronbach's alpha coefficient. Results: All items evaluated had a "excellent" classification, being: graphic presentation (52.65\%), readability (60.5\%), sequence of the algorithm (52.6\%), description of wound types (56.8\%), description of tissue types (52.6\%), presentation of types of exudate (57.9\%), presentation of signs of infection (57.9\%) and products to be used in dressing (50\%). The algorithm presented excellent internal consistency $(a=0.911$ ). According to $97.4 \%$ of the evaluations, the instrument is able to support health professionals in wounds evaluation. Conclusion: The algorithm showed internal reliability for evaluation and treatment of wounds.
\end{abstract}

DESCRIPTORS: Algorithms; Clinical protocols; Nursing evaluation; Healing; Stomatherapy.

\footnotetext{
${ }^{1}$ Universidade do Vale do Sapucaí - Faculdade de Ciências Médicas Dr. José Antônio Garcia Coutinho - Departamento de Enfermagem - Pouso Alegre/MG - Brazil.

${ }^{2}$ Universidade do Estado de Minas Gerais - Faculdade de Enfermagem - Departamento de Enfermagem - Belo Horizonte/MG - Brazil. Corresponding author: Geraldo Magela Salomé | Av. Francisco de Paula Quintanilha Ribeiro, 280 - Apart. 134 - Jabaquara | ZIP Code: 04330-020 - São Paulo/SP - Brazil | E-mail: salomereiki@yahoo.com.br
}

Received: Aug. 29, 2017 | Accepted: Dec. 05, 2017 


\section{RESUMO}

Objetivos: Elaborar um algoritmo para avaliação e tratamento de feridas e testar sua confiabilidade interna. Método: Estudo transversal e descritivo. Para a construção do algoritmo, foram realizadas revisão da literatura junto a bases de dados de ciências da saúde e consulta a livros e teses desta área publicados nos últimos 10 anos, utilizando como descritores: feridas agudas e crônicas; avaliação de feridas; instrumentos de avaliação; curativos; avaliação de enfermagem; cicatrização de feridas e cuidados de enfermagem; e algoritmos. Duzentos enfermeiros com experiência mínima de 12 meses em tratamento de feridas foram contatados e 38 deles completaram o questionário de avaliação. A consistência interna do algoritmo foi medida pelo coeficiente alfa de Cronbach. Resultados: Todos os itens avaliados tiveram classificação "ótimo", sendo eles: apresentação gráfica (52,65\%), facilidade de leitura (60,5\%), sequência do algoritmo (52,6\%), descrição dos tipos de ferida (56,8\%), descrição dos tipos de tecido (52,6\%), apresentação dos tipos de exsudato (57,9\%), apresentação dos sinais de infecção (57,9\%) e produtos a serem utilizados no curativo (50\%). O algoritmo apresentou excelente consistência interna $(a=0,911)$. Conforme $97,4 \%$ das avaliações, o instrumento é capaz de apoiar os profissionais de saúde na avaliação de feridas. Conclusão: $\bigcirc$ algoritmo mostrou confiabilidade interna para avaliação e tratamento de feridas.

DESCRITORES: Algoritmos; Protocolos clínicos; Avaliação em enfermagem; Cicatrização; Estomaterapia.

\section{RESUMEN}

Objetivos: Elaborar un algoritmo para evaluación y tratamiento de heridas y probar su confiabilidad interna. Método: Estudio transversal y descriptivo. Para la construcción del algoritmo, fueron realizadas revisión de la literatura junto a bases de datos de ciencias de la salud y consulta de libros y tesis de esta área publicadas en los últimos 10 años, utilizando como descriptores: heridas agudas y crónicas; evaluación de heridas; instrumentos de evaluación; vendaje; evaluación de enfermería; cicatrización de heridas y cuidados de enfermería; y algoritmos. Fueron contactados doscientos enfermeros con experiencia mínima de 12 meses en tratamiento de heridas y 38 de ellos completaron el cuestionario de evaluación. La consistencia interna del algoritmo fue medida por el coeficiente alfa de Cronbach. Resultados: Todos los puntos evaluados tuvieron una clasificación de "excelente", siendo ellos: presentación gráfica (52,65\%), facilidad de lectura (60,5\%), secuencia del algoritmo (52,6\%), descripción de los tipos de herida (56,8 \%), descripción de los tipos de tejido (52,6\%), presentación de los tipos de exudado (57,9\%), presentación de los indicios de infección (57,9\%) y productos a ser utilizados en el vendaje (50\%). el algoritmo presentó excelente consistencia interna ( $\alpha=0,911)$. Según 97,4\% de las evaluaciones, el instrumento es capaz de apoyar a los profesionales de la salud en la evaluación de heridas. Conclusión: El algoritmo mostró confiabilidad interna para evaluación y tratamiento de heridas.

DESCRIPTORES: Algoritmos; Protocolos clínicos; Evaluación en enfermería; Cicatrización; Estomaterapia.

\section{INTRODUCTION}

The skin is considered the largest organ of the human body and its functions are indispensable to life. Like any organ, it is subject to aggressions due to intrinsic and extrinsic factors that may cause alterations in its constitution, such as cutaneous wounds, that can lead to functional disability ${ }^{1}$. The wound can be characterized by a skin damage that impairs the performance of functions. And it can be defined as the result of an unlimited variety of traumatic, ischemic, surgical, or pressure injuries that attack the histophysiological structure of the tegumental tissue $\mathrm{e}^{2-5}$.

The nursing professional has a fundamental role in the patient support, performing care in a holistic, technical and scientific way. Before the treatment of wounds, the nurse exercises highly relevant work.
This occurs naturally because the nurse follows daily the evolution of the lesion and evaluates, guides and executes the dressing because it has greater mastery of the technique, due to having, in its formation, curricular components aimed at this practice, to develop it as one of your assignments ${ }^{1-7}$.

The choice of the appropriate material for the dressing pass from the pathophysiological and biochemical knowledge of the tissue repair and, for this, it is highlighted the necessity for training and knowledge of the professionals who provide nursing care. Dressing is defined as a therapeutic means consisting in the cleaning and application of material on a wound for its protection, absorption and drainage of exudates, in order to improve the conditions of the wound bed. 
Dressings may be the definitive treatment itself on some occasions; in others, only an intermediate step for the surgical treatment ${ }^{8-12}$.

Healthcare professionals who are involved in wound treatment should always seek new knowledge, as scientific updates and advances in the technologies related to this practice are frequent, which makes this work challenging. It is not difficult to find professionals who have difficulty to identify the correct stage of healing and confuse the normal and abnormal characteristics associated with this process. Moreover, evaluating a wound can lead to varied interpretations because of its diversity in nature, shape and location, as well as the individual's perception and technical knowledge of each nurse, considering the subjective factors of evaluation ${ }^{13}$. It is necessary to adopt measurement instruments, scales, protocols and clinical guidelines to help professionals to assess risks, formulate diagnoses, determine a plan of care and plan preventive actions.

The algorithms consist of a finite sequence of welldefined instructions. They are primary tools in quality management, standing out as an important means in the organization of processes. In health, these instruments are simple, direct and easy to access; they give a complete view of the care process, presenting themselves as maps and serving as guides for decision-making ${ }^{14,15}$.

The lack of tools, protocols in the form of algorithms, available in the literature for the evaluation and treatment of wounds, especially those elaborated from the opinion/ agreement of the professionals involved in undergraduate education and in the assistance of the population, is highlighted.

\section{OBJECTIVES}

The present study had as objectives to elaborate an algorithm for evaluation and treatment of wounds and to evaluate its internal reliability.

\section{METHOD}

This cross-sectional and descriptive study was realized at the Samuel Libanio Clinical Hospital in Pouso Alegre (Minas Gerais, Brazil), with attending nurses and registered stomatherapist nurses (TISOBEST), registered at the Brazilian Stomatherapy Association (SOBEST), who accepted to participate in the study. Data collection was realized after the research project was approved by the Research Ethics Committee of the University of Vale do Sapucai (UNIVAS), under opinion $n^{\circ}$ 873593. All participants signed the Free and Informed Consent Term.

The study population had 38 nurses who answered the questionnaire to evaluate the developed instrument. The inclusion criteria were: to be 18 years of age or older, to be a certificate holder of a nursing graduation course, to be titled TISOBEST and registered at SOBEST and to have experience in caring for patients with wounds for at least 12 months. The criterion of non-inclusion was: to be a nurse with experience in wound treatment less than 12 months.

The therapeutic approach proposed in this study, the products proposed for use in dressings and their respective exchange times follow the standardization of the Samuel Libânio Clinical Hospital. (Table 1).

\section{Development of the algorithm for wound evaluation and treatment}

For the construction of the algorithm, a bibliographical review was realized in the databases of health sciences, including the Cochrane Library, Scientific Electronic Library Online (SciELO), Latin American and Caribbean Literature in Health Sciences (LILACS), Medical Literature Analysis and Retrieval System Online/US National Library of Medicine database (MEDLINE), International Nursing Index (INI) and Cumulative Index to Nursing and Allied Health Literature database (CINAHL), in addition to consulting books and theses of the area published in the last 10 years, using as descriptors: acute wounds and chronic wounds; wound evaluation; evaluation tools; dressings; nursing evaluation; wound healing and nursing care; and algorithms.

After extensive bibliographical research in national and international indexed journals and after the abstracts were read, articles describing the evaluation, measurement and classification of the wound, the type of tissue and exudate commonly present in the wounds and the types of dressings were selected and covers used in the treatment 
Table 1. Products proposed for use in dressings. Pouso Alegre, Minas Gerais, Brazil, 2015.

\begin{tabular}{|c|c|}
\hline Product & Exchange time \\
\hline Essential Fatty Acid & Every 24 hours \\
\hline Calcium alginate & $\begin{array}{l}24 \text { hours; infected wounds; } 48 \text { hours; clean wounds with bleeding; when saturated; } \\
\text { clean wounds or severe exudation }\end{array}$ \\
\hline Unna boot (for venous ulcers) & Weekly \\
\hline Activated carbon with silver & $\begin{array}{l}\text { In up to } 7 \text { days, depending on the amount of exudation or saturation of the dressing, } \\
\text { change before }\end{array}$ \\
\hline Collagenase & Every 24 hours \\
\hline Hydropolymer with ibuprofen & $\begin{array}{l}\text { At most every } 7 \text { days or change the dressing whenever fluid is present on the edges of } \\
\text { the foam pad }\end{array}$ \\
\hline Hydrocolloid & From 1 to 7 days, depending on the amount of exudation \\
\hline Hydrofiber with or without silver & It can stay for up to 14 days or switch when clinically indicated \\
\hline Hydrogel with or without alginate & From 1 to 3 days, depending on the amount of exudate \\
\hline Hydropolymers with or without silver & $\begin{array}{l}\text { At most every } 7 \text { days or change the dressing whenever fluid is present on the edges of } \\
\text { the foam pad }\end{array}$ \\
\hline Papain $2 \%, 4 \%, 6 \%, 10 \%, 20 \%$ or more & At most, every 24 hours \\
\hline Nanocrystalline silver & From 3 to 8 days, depending on the amount of exudation \\
\hline Silver sulfadiazine (for burns) & At most every 12 hours or when secondary coverage is saturated \\
\hline
\end{tabular}

of wounds. These procedures aided in obtaining data for the construction of the algorithm. Since no study similar to the one proposed in this study was found in the literature, the algorithm was elaborated in a sequence described in three stages, including wound evaluation, classification of tissue types and establishment of therapeutic management more appropriate.

The first step comprises the steps of wound evaluation and includes measurement, margin type, tissue type, type and amount of exudate present and signs of inflammation and/or infection. The second stage classifies the main types of tissues found in the wound, being: devitalized tissue, granulation tissue and epithelial tissue. The third step presents treatment suggestions. In this step, the algorithm provides suggestions of therapeutic behavior, according to the types of tissue and exudate identified in the lesion, in order to promote the moist environment and the debridement of the devitalized tissues present and to stimulate the healing. For this study, the therapeutic approach was proposed using the standardized types of coverage at the Samuel Libanio Clinical Hospital and the municipal health network.

\section{Evaluation of the internal reliability of the algorithm}

To verify the internal reliability of the algorithm, it was submitted to the evaluation of 38 judges, being these nurses with experience in evaluating and treating lesions. The judges analyzed the content, presentation, clarity and understanding of the instrument.

Initially, 200 professionals were contacted by electronic means (e-mail), in which the study was presented. All e-mails were sent on February 21, 2015 between 08:00 and 12:00 am. The professional who agreed to participate in the research accessed the link in the text of the message, filled out the questionnaire completely and sent it by e-mail to the sender. The questionnaire was available in the system until March 1, 2015. The evaluation script of the algorithm was constructed after literature review related to the theme $\mathrm{e}^{1,3,9-13,15-19}$.

Thirty-eight judges completed the evaluation questionnaire. In accepting to participate in the research, the judges evaluated the following items: graphical presentation, readability, sequence of the algorithm, description of tissue types, types and quantity of exudate, 
measurement and classification of the wound. Regarding the description of the dressing types, the algorithm provides information capable of supporting professionals in choosing the most appropriate dressing. The response alternatives were: excellent, good, fair and poor; space was provided for comments and/or suggestions.

It was considered a percentage of $70 \%$ of the compatible positive responses (excellent, good) for the classification of the algorithm as applicable.

The data obtained were tabulated in Excel® worksheet (Microsoft Corp., Redmond, WA, USA). The Statistical Package for Social Sciences (SPSS), version 2, was used for statistical analysis. It was used the Cronbach alpha coefficient (reliability of the algorithm), the non-parametric Friedman test and the Chi-square test of independence. For all statistical tests, significance level $\alpha$ was set at $5 \%(\mathrm{p} \leq 0.05)$.

\section{RESULTS}

Most of the participating professionals (68.43\%) had time of graduation of 11 years or more, eight (21.05\%) had between six and 10 years of graduation, and four $(10.52 \%)$ had between one and five years of graduate. As for the academic training of the participants, 20 $(52.63 \%)$ of these were specialists, 11 (28.95\%) had a full doctorate and seven (18.42\%) had a master's degree.
Table 2 presents the participants' questions and answers regarding the algorithm. It was observed that the highest percentage (60.5\%) of "excellent" evaluations was attributed to the readability item and the lowest percentage (50.0\%) was attributed to product suggestions to be used in dressings; in the "good" evaluation, the highest percentage (47.4\%) was for the graphic presentation and the lowest percentage (29.7\%), for the item description of wound types; in the "regular" evaluation, the highest percentage (10.8\%) was for the item description of the types of wounds and the lowest $(2.6 \%)$, for the item reading facility. Two questions were evaluated as "bad", $2.7 \%$ for description of wound types and $2.6 \%$ for suggestion of products to be used in dressings. Only the graphical presentation item did not present statistical significance between the proportions of "good" and "excellent" response. The numbers highlighted in Table 2 refer to the maximum and minimum percentages of "bad", "regular", "good" and "excellent" answers.

Thirty-seven $(97.4 \% ; \mathrm{p}<0.001)$ participants answered that the algorithm provides information that can help health professionals choose the dressing, characterizing the instrument as a tool capable of guiding health professionals in deciding the best dressing to be used on the wound.

The association between the degree of academic qualification of the evaluators and the answers given for the different items is presented in Table 3. Regarding

Table 2. Characterization and content of the algorithm, according to the evaluation of the research participants. Pouso Alegre, Minas Gerais, Brazil, 2015.

\begin{tabular}{|c|c|c|c|c|c|c|c|c|c|c|c|}
\hline \multirow{2}{*}{ Questions for algorithm evaluation } & \multicolumn{2}{|c|}{ Bad } & \multicolumn{2}{|c|}{ Regular } & \multicolumn{2}{|c|}{ Good } & \multicolumn{2}{|c|}{ Excellent } & \multicolumn{2}{|c|}{ Total } & \multirow{2}{*}{ Value $p$} \\
\hline & $\mathbf{n}$ & $\%$ & $\mathbf{n}$ & $\%$ & $\mathbf{n}$ & $\%$ & $\mathbf{n}$ & $\%$ & $\mathrm{n}$ & $\%$ & \\
\hline About the graphical presentation & 0 & 0 & 0 & 0 & 8 & 47.4 & 20 & 52.6 & 38 & 100 & 0.871 \\
\hline About the readability & 0 & 0 & 1 & 2.6 & 14 & 36.8 & 23 & 60.5 & 38 & 100 & $0.001 *$ \\
\hline About the algorithm sequence & 0 & 0 & 2 & 5.3 & 16 & 42.1 & 20 & 52.6 & 38 & 100 & $0.001 *$ \\
\hline About the description of wound types & 1 & 2.7 & 4 & 10.8 & 11 & 29.7 & 21 & 56.8 & 37 & 100 & $0.001 *$ \\
\hline About the description of tissue types & 0 & 0 & 4 & 10.5 & 14 & 36.8 & 20 & 52.6 & 38 & 100 & $0.001 *$ \\
\hline $\begin{array}{l}\text { About the presentation of the types of } \\
\text { exudate }\end{array}$ & 0 & 0 & 3 & 7.9 & 13 & 34.2 & 22 & 57.9 & 38 & 100 & $0.001 *$ \\
\hline $\begin{array}{l}\text { About the presentation of signs of } \\
\text { infection }\end{array}$ & 0 & 0 & 4 & 10.5 & 12 & 31.6 & 22 & 57.9 & 38 & 100 & $0.001 *$ \\
\hline $\begin{array}{l}\text { About the suggestion of the products to } \\
\text { be used in dressings }\end{array}$ & 1 & 2.6 & 2 & 5.3 & 16 & 42.1 & 19 & 50.0 & 38 & 100 & $0.001 *$ \\
\hline
\end{tabular}

Friedman's test. * Statistical significance $(p<0.05)$ 
Table 3. Judges' evaluation about the graphical presentation and wound evaluation items, according to degree of academic qualification. Pouso Alegre, Minas Gerais, Brazil, 2015.

\begin{tabular}{|c|c|c|c|c|c|c|c|c|c|}
\hline \multirow{3}{*}{ Evaluated item } & \multicolumn{6}{|c|}{ Degree } & \multirow{2}{*}{\multicolumn{2}{|c|}{ Total }} & \multirow{3}{*}{ Value $p$} \\
\hline & \multicolumn{2}{|c|}{ Specialization } & \multicolumn{2}{|c|}{ Master } & \multicolumn{2}{|c|}{ Doctorate } & & & \\
\hline & $\mathrm{n}$ & $\%$ & $\mathrm{n}$ & $\%$ & $n$ & $\%$ & $\mathrm{n}$ & $\%$ & \\
\hline \multicolumn{10}{|l|}{ Graphical presentation } \\
\hline Good & 7 & 35.0 & 3 & 42.9 & 8 & 72.7 & 18 & 47.4 & \multirow{2}{*}{0.175} \\
\hline Excellent & 13 & 65.0 & 4 & 57.1 & 3 & 27.3 & 20 & 52.6 & \\
\hline Total & 20 & 100 & 7 & 100 & 11 & 100 & 38 & 100 & \\
\hline \multicolumn{10}{|l|}{ Readability } \\
\hline Regular & 0 & 0 & 0 & 0 & 1 & 9.0 & 1 & 2.6 & \multirow{2}{*}{0.226} \\
\hline Good & 5 & 25.0 & 4 & 57.1 & 5 & 45.5 & 14 & 36.8 & \\
\hline Excellent & 15 & 75.0 & 3 & 42.9 & 5 & 45.5 & 23 & 60.5 & \\
\hline Total & 20 & 100 & 7 & 100 & 11 & 100 & 38 & 100 & \\
\hline
\end{tabular}

\section{Sequence of the algorithm}

\begin{tabular}{|c|c|c|c|c|c|c|c|c|}
\hline Regular & 0 & 0 & 0 & 0 & 2 & 18.2 & 2 & 5.3 \\
\hline Good & 6 & 30.0 & 4 & 57.1 & 6 & 54.5 & 16 & 42.1 \\
\hline Excellent & 14 & 70.0 & 3 & 42.9 & 3 & 27.3 & 20 & 52.6 \\
\hline Total & 20 & 100 & 7 & 100 & 11 & 100 & 38 & 100 \\
\hline
\end{tabular}

\section{Description of wound types}

\begin{tabular}{|c|c|c|c|c|c|c|c|c|}
\hline $\mathrm{Bad}$ & 0 & 0 & 0 & 0 & 1 & 9.1 & 1 & 2.7 \\
\hline Regular & 1 & 5.0 & 0 & 0 & 3 & 27.3 & 4 & 10.8 \\
\hline Good & 3 & 15.0 & 4 & 66.7 & 4 & 36.4 & 11 & 29.7 \\
\hline Excellent & 16 & 80.0 & 2 & 33.3 & 3 & 27.3 & 21 & 56.8 \\
\hline Total & 20 & 100 & 6 & 100 & 11 & 100 & 37 & 100 \\
\hline
\end{tabular}

\section{Description of tissue types}

\begin{tabular}{|c|c|c|c|c|c|c|c|c|c|}
\hline Regular & 1 & 5.0 & 0 & 0 & 3 & 27.3 & 4 & 10.5 & \multirow{3}{*}{$0.015^{*}$} \\
\hline Good & 4 & 20.0 & 4 & 57.1 & 6 & 54.5 & 14 & 36.8 & \\
\hline Excellent & 15 & 75.0 & 3 & 42.9 & 2 & 18.2 & 20 & 52.6 & \\
\hline Total & 20 & 100 & 7 & 100 & 11 & 100 & 38 & 100 & \\
\hline \multicolumn{10}{|c|}{ Description of types of exudate } \\
\hline Regular & 1 & 5.0 & 0 & 0 & 2 & 18.2 & 3 & 7.9 & \multirow{4}{*}{0.100} \\
\hline Good & 4 & 20.0 & 3 & 42.9 & 6 & 54.5 & 13 & 34.2 & \\
\hline Excellent & 15 & 75.0 & 4 & 57.1 & 3 & 27.3 & 22 & 57.9 & \\
\hline Total & 20 & 100 & 7 & 100 & 11 & 100 & 38 & 100 & \\
\hline
\end{tabular}

Presentation of signs of inflammation/infection

\begin{tabular}{|c|c|c|c|c|c|c|c|c|c|}
\hline Regular & 1 & 5.0 & 1 & 14.3 & 2 & 18.2 & 4 & 10.5 & \multirow{4}{*}{$0.021 *$} \\
\hline Good & 3 & 15.0 & 2 & 28.6 & 7 & 63.6 & 12 & 31.6 & \\
\hline Excellent & 16 & 80.0 & 4 & 57.1 & 2 & 18.2 & 22 & 57.9 & \\
\hline Total & 20 & 100 & 7 & 100 & 11 & 100 & 38 & 100 & \\
\hline \multicolumn{10}{|c|}{ Suggestion of products for dressings } \\
\hline $\mathrm{Bad}$ & 0 & 0 & 0 & 0 & 1 & 9.1 & 1 & 2.6 & \multirow{4}{*}{$0.039 *$} \\
\hline Regular & 1 & 5.0 & 0 & 0 & 1 & 9.1 & 2 & 5.3 & \\
\hline Good & 5 & 25.0 & 3 & 42.9 & 8 & 72.7 & 16 & 42.1 & \\
\hline Excellent & 14 & 70.0 & 4 & 57.1 & 1 & 9.1 & 19 & 50.0 & \\
\hline Total & 20 & 100 & 7 & 100 & 11 & 100 & 38 & 100 & \\
\hline
\end{tabular}

Pearson's test, Fisher's exact test and Chi-square test. *Statistical significance $(p<0.05)$. 
the item graphical presentation, it was observed that $72.7 \%$ of the judges with a doctorate and $65 \%$ of the specialists evaluated it as "excellent", while $57.1 \%$ of the participants with masters rated it as good. As for the readability item, $75 \%$ of the specialists and $45 \%$ of the doctors rated it as "excellent", while $57.1 \%$ of the masters and $45.5 \%$ of the doctors evaluated it as "good". Regarding the sequence of the algorithm, $70 \%$ of the specialists and $42.9 \%$ of the masters rated it as "excellent", while $57.1 \%$ of the masters and $54.5 \%$ of the doctors evaluated it as "good". Regarding the item description of wound types, $80 \%$ of the specialists and $33.3 \%$ of the masters rated it as "excellent", while $66.7 \%$ of the masters and $36.4 \%$ of the doctors evaluated it as "good". Regarding the item description of tissue types, $75 \%$ of the experts rated it as "excellent", while $57.1 \%$ of the masters and $54.5 \%$ of the doctors rated it as "good". Regarding the presentation of types of exudate, $75 \%$ of the specialists and $57.1 \%$ of the masters rated it as "excellent", while $54.5 \%$ of the doctors evaluated it as "good". As for the item inflammation or infection, $80 \%$ of the specialists and $57.1 \%$ of the masters rated it as "excellent", while $63.6 \%$ of the doctors rated it as "good". Regarding the suggestion of the products to be used in dressings, $70 \%$ of the specialists and $57.1 \%$ of the masters rated it as "excellent", while $72.7 \%$ of the doctors rated it as "good".

Table 4 shows that all the questions presented in the algorithm contributed favorably to the internal consistency of the instrument, with an a of 0.911 considered as excellent.

In Table 5, the suggestions for changes submitted by the judges are described. The suggestions were considered with theoretical basis.

The final version of the algorithm developed in this study for wound evaluation and treatment, including the suggestions presented by the judges, is shown in Fig 1 .

Table 4. Internal consistency of the questions presented in the algorithm. Pouso Alegre, Minas Gerais, Brazil, 2015.

\begin{tabular}{|c|c|c|c|c|}
\hline $\begin{array}{l}\text { Questions presented in the algorithm } \\
\quad(\text { Cronbach alpha total }=0.911)\end{array}$ & $\begin{array}{l}\text { Average } \\
\text { of the } \\
\text { algorithm } \\
\text { if it deleted } \\
\text { the item }\end{array}$ & $\begin{array}{l}\text { Variance } \\
\text { of the } \\
\text { algorithm if it } \\
\text { deleted } \\
\text { the item }\end{array}$ & $\begin{array}{l}\text { Correlation } \\
\text { of the item } \\
\text { with the } \\
\text { algorithm, if } \\
\text { it deleted the } \\
\text { item }\end{array}$ & $\begin{array}{l}\text { Cronbach } \\
\text { alpha } \\
\text { if it deleted } \\
\text { the item }\end{array}$ \\
\hline About the graphical presentation & 31.16 & 14.473 & 0.604 & 0.909 \\
\hline About the readability & 31.11 & 14.544 & 0.522 & 0.914 \\
\hline About the algorithm sequence & 31.22 & 13.341 & 0.758 & 0.896 \\
\hline About the description of wound types & 31.27 & 12.480 & 0.699 & 0.903 \\
\hline About the description of tissue types & 31.27 & 12.425 & 0.862 & 0.886 \\
\hline About the presentation of the types of exudate & 31.19 & 13.047 & 0.763 & 0.895 \\
\hline About the presentation of signs of inflammation & 31.22 & 12.619 & 0.807 & 0.891 \\
\hline About the suggestion of the products to be used in dressings & 31.30 & 12.881 & 0.707 & 0.901 \\
\hline
\end{tabular}

Table 5. Qualitative synthesis of the alterations suggested by the judges related to the algorithm for wound evaluation. Pouso Alegre, Minas Gerais, Brazil, 2015.

\begin{tabular}{c} 
Judge \\
1 "I suggest that when referring to eschar replace by dry necrosis and in parentheses place eschar" \\
\hline 4 \\
\hline
\end{tabular}



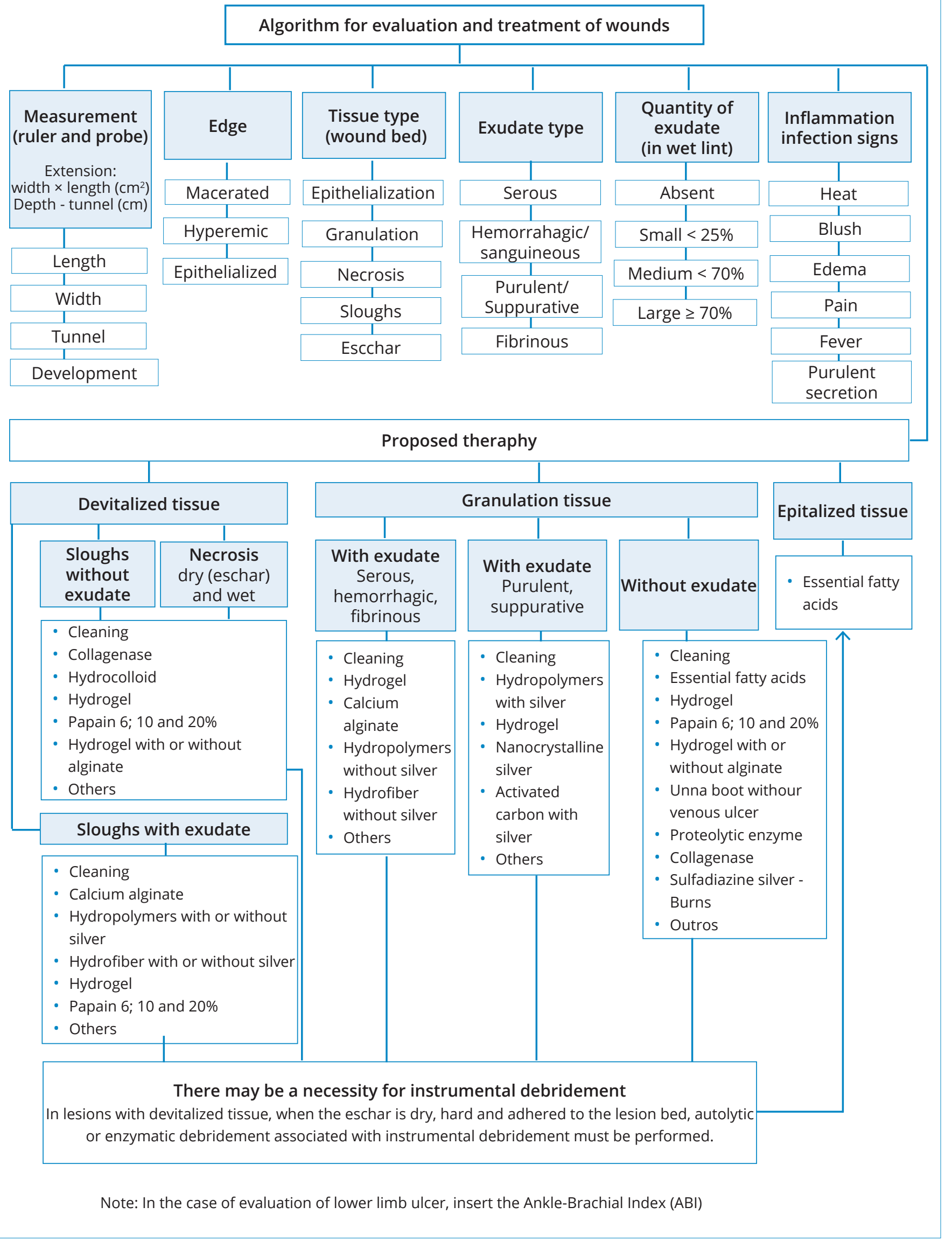

Figure 1. Final version of the algorithm for wound evaluation and treatment. Pouso Alegre, Minas Gerais, Brazil, 2015. 


\section{DISCUSSION}

The present study developed an algorithm and computational system to evaluate and treat wounds, supplying, in a scientific and technological way, the lack of these products. For this, it counted on the knowledge and experience of professionals of the area, being the majority graduated more than 11 years, to act like judges, being these 20 specialists, seven masters and 11 doctors. Such procedures corroborate with other authors who used similar methods ${ }^{6,20}$.

Wounds present a high challenge for health professionals, due to their innumerable characteristics related to the patient, the process of installation, treatment and cure. Assistance to the patient with wounds begins with the evaluation and recording of all data, always remembering that each patient and each lesion are unique, and this step must be performed before any therapeutic procedure is instituted ${ }^{21}$.

The use of wound evaluation instruments favors the systematic registration of care, enables continuity of care and favors the quality of care. The systematic treatment of wounds minimizes healing time and allows the analysis of costs and benefits of the treatment used ${ }^{10,13,21,22}$.

The development of an algorithm provides an important contribution to health services. The quality of health care should be measured by the best application of available resources, in order to obtain the highest possible health indexes for system users, at the lowest cost and with the lowest possible risk to the patient ${ }^{23}$.

Usually, wounds are often treated in different ways, by different professionals, in an unsystematic way. The exchange of the dressings is often not specified and the systematic evaluation of the wounds is not performed, hampering the evolutionary analysis of these. Health professionals should evaluate the wounds to judge the evolution of these, and their evaluation must contain objective measures, realized periodically from an initial evaluation ${ }^{6,13,22}$. It is necessary to use guidelines, protocols, booklets and algorithms that provide professionals with guidelines for wound evaluation, since adequate documentation guarantees the success of the treatment and the evolutionary follow-up of the wounds. The lack of standardization in the data registry can lead to the execution of individualized and more convenient techniques, hampering the healing process ${ }^{13,19}$.

The choice of the algorithm theme for wound evaluation and treatment emerged from reflections on the difficulties professionals have in assessing the wound and performing the indication of optimal coverage that promotes moist and healing. The elaborated and validated algorithm includes all items necessary to evaluate a wound (wound measurement, tissue type, exudate, amount of exudate and signs of inflammation and/or infection) and suggests types of coverage to be used in the treatment. Most of the evaluations made by the judges considered positively (good and excellent) each question of the algorithm and pointed the instrument as a tool capable of helping the health professional in the assessment of the wound, as well as in choosing the appropriate dressing.

In a study by Stephen-Haynes ${ }^{18}$, an algorithm for wound evaluation was developed and it was determined that it should describe a strategic process for the evaluation of products and the promotion of healing. Wound treatment is an increasingly complex process given the variety of products and coverage available on the market. The elaboration of an algorithm should be strongly based on the literature and clinical evidence in order to provide technical, clinical, administrative and financial support, always aiming at improving patient care and the best results for the institution.

In the present study, during the process of reliability analysis of the instrument, the judges' suggestions were included, which provided relevant information for modification of writing and illustration. The majority of judges agreed with the applicability of the algorithm to clinical practice, that is, considered this an important tool that contains information capable of supporting the professional's decision to evaluate the wound and choose the ideal coverage for wound healing.

Evaluating a wound is to describe its clinical characteristic, specifying its location, its size, its appearance and characteristics of the skin around it and the exudate. The evaluation of the wounded patient should be global, systematized and interdisciplinary, clarifying the diagnosis, the type of wound and the factors that interfere in healing ${ }^{13,18}$.

In another study in which the authors developed and validated an algorithm for wound treatment, it was evidenced that this algorithm should be developed to streamline the clinical decision-making process and should guide efforts in prevention and individualized treatment to provide care with quality and safety. It is necessary that the algorithm is constructed based on the literature and clinical guidelines and that its validation is performed and its reliability tested ${ }^{12}$. The validation of the instrument, the reliability tests and 
the statistical analyzes allow us to affirm that the algorithm acts as a reference in the delivery and standardization of care $^{23,24}$. This task is quite difficult because it involves several subjective factors, such as professional knowledge, which is usually quite variable and sometimes conflicting with other professionals regarding identification, nature, form and location of the wound and physiological aspects of the lesion. The use of standardized instruments facilitates the work of health professionals, as it makes standard the wound evaluation procedure and the choice of treatment, besides allowing analyzes of cost-benefit, systematization of care and better quality of life to the patient $\mathrm{t}^{7-12}$.

In evaluating wounds, practitioners need to make decisions based on knowledge of the skin anatomy, principles of tissue repair physiology, and the factors that interfere with them. These professionals must know the types of wounds and the various forms of treatment existing, besides the ability to observe the tissue loss, the clinical aspect of the lesion, its location and size, the presence of exudate, skin characteristics that surround the wound, pain and signs of infection ${ }^{7-12}$. In an earlier study ${ }^{13}$, it was concluded that there were no records of algorithms, prescription, evolution and treatment of wounds, and nurses were free to register the progression or regression of the wound against the used therapy, but this fact does not allow a real knowledge of the actions of the nurses in relation to patients with wounds. Faced with this problem, it is essential to establish conduits with a view to reducing the incidence of these aggravations, as well as minimizing the damages and complications caused by their evolution, which points out the necessity for the institution to establish preventive and evaluative measures ${ }^{15}$.

Algorithms are an excellent strategy for standardizing activities because they are organized in a way that synthesizes large operations or processes into a finite set of welldefined instructions that can be performed systematically. Its presentation is very simple, direct and easy to access, allowing a complete view of the whole care process, factors that make them important tools for quality management of the services because they present themselves as excellent means of work organization, serving as guides for the decision-making, especially the more complex ones ${ }^{15}$. Protocols, algorithms, booklets, flowcharts and guidelines are considered important tools for coping with various problems in the care and management of health services.
These are instruments guided by guidelines of a technical, organizational and political nature and are based on studies validated by scientific evidence. The use of these instruments aims at the standardization of clinical, surgical and preventive procedures. The development of new tools requires the incorporation of new technologies that meet the treatment needs, as well as the organizations that provide health care ${ }^{25}$.

As director of nursing at a large hospital and high complexity, the author Salomé GM often perceives the difficulty of professionals in evaluating patients with wounds. Although it is a school hospital, having a specialized wound care service and having protocols described in all units, there are difficulties in relation to the standardization of the ducts and adequate recording of the activities realized ${ }^{11}$.

The consultation of professionals with the procedures manuals is limited, mainly because the content is very theoretical and the descriptions are very long. In this way, the proposal of this study will facilitate the access of the professionals to the information, as well as will allow the formation of a database, due to the development of the computational version of mobile technology of the algorithm. Among the many advantages already discussed in the present study products, it is important to point out that the tools for evaluating wounds besides being easily accessible to professionals are also inexpensive.

\section{CONCLUSION}

After reviewing the literature, an algorithm was developed for wound evaluation and treatment suggestion directed to health professionals, which demonstrated internal reliability by analyzing the evaluation questionnaire responses provided by the study participants.

\section{AUTHORS CONTRIBUTION}

Conceptualization, Cunha JB; Dutra RAA and Salomé GM; Methodology, Salomé GM; Investigation, Cunha JB; Dutra RAA and Salomé GM; Writing First version, Cunha JB; Dutra RAA and Salomé GM; Writing - Review \& Editing, Salomé GM; Recursos, Salomé GM; Supervision, Salomé GM. 


\section{REFERENCES}

1. Morais GFC, Oliveira SHS, Soares MJGO. Avaliação de feridas pelos enfermeiros de instituições hospitalares da rede pública. Texto Contexto Enferm. 2008;17(1):98-105. doi: 10.1590/s0104-07072008000100011

2. Salomé GM, Ferreira LM. Impact of non-adherent Ibuprofen foam dressing in the lives of patients with venous ulcers. Rev Col Bras Cir. 2017;44(2):116-24. doi: 10.1590/010069912017002002

3. Metcalf DG, Bowler PG, Hurlow J. A clinical algorithm for wound biofilm identification. J Wound Care. 2014;23(3):13742. doi: 10.12968/jowc.2014.23.3.137

4. Salomé GM, de Almeida SA, Ferreira LM. Association of sociodemographic factors with hope for cure, religiosity, and spirituality in patients with venous ulcers. Adv Skin Wound Care. 2015;28(2):76-82. doi: 10.1097/01. asw.0000459844.07689.02

5. Salomé GM, Santos LF, Cabeceira HS, Panza AMM, de Paula MAB. Knowledge of undergraduate nursing course teachers on the prevention and care of peristoma skin. J Coloproctol. 2014;34(4):224-30. doi: 10.1016/j. jcol.2014.05.008

6. Almeida SA, Silveira MM, do Espírito Santo PF, Pereira RC, Salomé GM. Assessment of the quality of life of patients with diabetes mellitus and foot ulcers. Rev Bras Cir Plast. 2013;28(1):142-6. doi: 10.1590/s198351752013000100024

7. Espírito Santo PF, de Almeida SA, Silveira MM, Salomé GM, Ferreira LM. Use of the Pressure Ulcer Scale for Healing tool to evaluate the healing of chronic leg ulcers. Rev Bras Cir Plast. 2013;28(1):133-41. doi: 10.1590/s198351752013000100023

8. Smaniotto PHS, Dalli R, Carvalho VF, Ferreira MC. Tratamento clínico das feridas - curativos. Rev Med. 2010;89(3-4):13741. doi: 10.11606/issn.1679-9836.v89i3/4p137-141

9. Dutra RM, Silva ML, Coelho MMF, Azevedo MCA, Bezerra STF Profile of patients followed by the interdisciplinary wound care commission. J Nurs UFPE on line. 2017;11(2):941-9.

10. Santos VLCG, Sellmer D, Massulo MME. Inter rater reliability of Pressure Ulcer Scale for Healing (PUSH) in patients with chronic leg ulcers. Rev Latino-Am Enfermagem. 2007;15(3):391-6. doi: 10.1590/s010411692007000300005

11. Gardona RGB, Ferracioli MM, Salomé GM, Pereira MTJ. Avaliação da qualidade dos registros dos curativos em prontuários realizados pela enfermagem. Rev Bras Cir Plast. 2013;28(4):686-92.

12. Almeida SA, Moreira CNO, Salomé GM. Pressure Ulcer Scale for Healing no acompanhamento da cicatrização em pacientes idosos com úlcera de perna. Rev Bras Cir Plast. 2014;29(1):120-7. doi: 10.5935/2177-1235.2014rbcp0020

13. Bajay HM, Araújo IEM. Validação e confiabilidade de um instrumento de avaliação de feridas. Acta Paul Enferm. 2006;19(3):290-5. doi: 10.1590/s010321002006000300006

14. Hess CT. Processes + workflows drive documentation compliance. Adv Skin Wound Care. 2013;26(10):480. doi: 10.1097/01.asw.0000434586.86901.4c

15. Pott FS, Ribas JD, da Silva OBM, de Souza TS, Danski MTR, Marineli MJ. Algoritmo de prevenção e tratamento de úlcera por pressão. Cogitare Enferm. 2013;18(2):238-44. doi: 10.5380/ce.v18i2.26085

16. Beitz JM, van Rijswijk L. Content validation of algorithms to guide negative pressure wound therapy in adults with acute or chronic wounds: a cross-sectional study. Ostomy Wound Manage. 2012;58(9):32-40.

17. Rijswijk L, Beitz JM. Creating a pressure ulcer prevention algorithm: systematic review and face validation. Ostomy Wound Manage. 2013;59(11):28-40.

18. Stephen-Haynes J. Development of an algorithm as an implementation model for a wound management formulary across a UK health economy. J Wound Care. 2013;22(12):692-8. doi: 10.12968/jowc.2013.22.12.692

19. Metcalf DG, Bowler PG, Hurlow J. A clinical algorithm for wound biofilm identification. J Wound Care. 2014;23(3):13742. doi: 10.12968/jowc.2014.23.3.137

20. Rijswijk L, Beitz JM. Pressure ulcer prevention algorithm content validation: a mixed-methods, quantitative study. Ostomy Wound Manage. 2015;61(4):48-57.

21. Carvalho MRF, Salomé GM, Ferreira LM. Construction and validation of algorithm for treatment of pressure injury. J Nurs UFPE on line. 2017;11(10):4171-83.

22. Santos VLCG, Carvalho VF. Reapresentando o instrumento Pressure Ulcer Scale for Healing (PUSH) para avaliação de úlceras por pressão e úlceras crônicas de perna. ESTIMA, Braz J Enterestomal Ther. 2009;7(2):19-27.

23. Beitz JM, van Rijswijk L. A cross-sectional study to validate wound care algorithms for use by registered nurses. Ostomy Wound Manage. 2010;56(4):46-59.

24. Beitz J, Gerlach M, Ginsburg P, Ho M, McCann E, Schafer $V$, et al. Content validation of a standardized algorithm for ostomy care. Ostomy Wound Manage. 2010;56(10):22-38.

25. Costa RKS, Torres GV, Salvetti MG, Azevedo IC, Costa MAT. Instrument for evaluating care given by undergraduate nursing students to people with wounds. Rev Esc Enferm USP. 2015;49(2):317-25. doi: 10.1590/s0080623420150000200018 